\title{
Oral Tongue Squamous Cell Carcinoma (OTSCC): Alcohol and Tobacco Consumption versus Non- Consumption. A Study in a Portuguese Population
}

\author{
Rui ALBUQUERQUE ${ }^{1}$ \\ José LÓPEZ-LÓPEZ ${ }^{1}$ \\ Antonio MARÍ-ROIG ${ }^{2}$ \\ Enric JANÉ-SALAS ${ }^{1}$ \\ Xavier ROSELLÓ-LLABRÉS ${ }^{1}$ \\ Jorge Rosa SANTOS 3
}

\author{
${ }^{1}$ Department of Oral Medicine, University of Barcelona, Catalonia, Spain \\ ${ }^{2}$ Department of Oral and Maxillofacial Surgery, Bellvitge University Hospital, University of Barcelona, Catalonia, Spain \\ ${ }^{3}$ Department of Head and Neck Surgery, Instituto Portugues de Oncologia de Lisboa - Francisco Gentil, \\ Lisbon, Portugal
}

\begin{abstract}
There has been an increase in the incidence of carcinoma of the tongue, particularly among alcohol and tobacco non-users. However, the number of studies that would allow a better understanding of etiological factors and clinical features, particularly in the Portuguese population, is very limited. This study was based on patients with squamous cell carcinoma of the anterior two thirds of the tongue that were treated at the Department of Head and Neck Surgery of the "Instituto Portugues de Oncologia de Lisboa - Francisco Gentil" (IPOLFG) in Lisbon, Portugal, between January 1, 2001 and December 31, 2009. The patients were divided in alcohol and tobacco users and non-users in order to evaluate the differences between these 2 groups based on gender, age, tumor location, denture use, and tumor size, metastasis and stage. Of the 354 cases, 208 were users and 146 were non-users. The main location in both groups was the lateral border of the tongue. Denture use showed no significant effect in both study groups. It was possible to conclude that patients who did not drink or smoke were older and presented with smaller tumor size, lower incidence of ganglion metastasis and lower tumor stage compared with alcohol and tobacco users.
\end{abstract}

Key Words: Squamous cell carcinoma, alcohol, tobacco.

\section{INTRODUCTION}

There is a strong association between the frequent consumption of alcohol and tobacco and the incidence of head and neck cancer, and reduction of their consumption has been associated with the prevention of cancer development $(1,2)$. Recently, the incidence of head and neck carcinoma in the USA has decreased and several prevention campaigns were also developed in different countries in order to reduce the smoking habits (3).

Considering that $95 \%$ of the head and neck cancers are squamous cell carcinomas, clinical behavior varies according to their location. The carcinoma of the tongue represents $25 \%$ to $50 \%$ of all cases of oral squamous cell carcinoma (OSCC) (4), with the lateral borders and the anterior two thirds the most commonly affected locations.

Despite the fact that the combined effects of tobacco and alcohol consumption may increase the risk of developing carcinoma $(1,2)$, there are other factors that play an important role in the development of carcinoma in patients without history of drinking and smoking. Although not completely clarified, several factors have been referred for this particular group such as human papilloma virus (HPV), diet and genetic factors $(2,4-$ 7). In fact, although the global incidence of OSCC has decreased, the incidence of oral cancer has increased among people less than 40 years of age, a group not normally associated with the consumption of alcohol and tobacco. Indeed, in this group, the proportion of women 
with oral tongue squamous cell carcinoma (OTSCC) is higher when compared with the general population (8-10). Regarding the oral cavity, few studies have evaluated the OTSCC of the anterior two thirds of the tongue, especially among non-smokers and non-drinkers $(2,11)$. In fact, there is no study developed among the Portuguese population with the previous characteristics. Therefore, the purpose of this study was to examine the differences between patients with and without history of alcohol and tobacco consumption in a Portuguese population with OTSCC of the anterior two thirds of the tongue. The differences between these two groups regarding age, location, denture use, size of the tumor $(\mathrm{T})$, metastasis $(\mathrm{N})$ and stage was analyzed.

\section{MATERIAL AND METHODS}

A retrospective review was carried out with all patients treated at the Department of Head and Neck Surgery of the "Instituto Portugues de Oncologia de Lisboa - Francisco Gentil" (IPOLFG) in Lisbon", Portugal, between January 1, 2001 and December 31, 2009. The collected data were: gender, age, location of the carcinoma (dorsal or ventral surface, right or left lateral borders, and floor of the mouth), tobacco and alcohol consumption (users versus non-users), denture use, tumor size (T1, T2, T3), presence of ganglion metastasis ( $\mathrm{N}+$ includes $\mathrm{N} 1, \mathrm{~N} 2$ and $\mathrm{N} 3$ and $\mathrm{N} 0$, when there was non ganglion metastasis) and tumor stage (I, II, III and IV). Denture use comprised use of removable acrylic or metal partial or complete denture at the time of diagnosis or when the first symptoms appeared, as described by the patient. Tumor size, metastases and tumor stage were analyzed after the postoperative results and according to 1987-92 UICC TNM classification (12).

Concerning tobacco and alcohol consumption, all patients who smoked up to 10 cigarettes/day and those who consumed more than $25 \mathrm{~g} /$ day of alcohol were considered as regular smokers and alcohol users respectively. Non-users were those who did not smoke or consume any alcohol at the time of the diagnosis or had abandoned the habit more than 2 years ago.

As inclusion criterion, all participants enrolled in the study received a positive histopathological result for OTSCC. Patients with OTSCC that did not display any correlation with gender, alcohol consumption, tobacco use, denture use and primary site of the carcinoma, cases of OTSCC with systemic metastases or invasion of the adjacent structures ( $\mathrm{Mx}$ and T4NxMx.), and those who had received treatment for more than one carcinoma were excluded from the study.

Data were analyzed using the Statistical Package for Social Sciences (SPSS) software, version 18.0 (SPSS Inc., Chicago, IL, USA). Data were grouped as belonging to alcohol and tobacco users (ATU) and alcohol and tobacco non-users (ATNU). Comparisons between ATU and ATNU were performed using binomial distribution for gender and denture use, Student's t-test (t) for age, and Pearson's Chi-square $\left(\chi^{2}\right)$ test for the TNM classification of the tumor. The results of the null hypothesis were less than or equal to 0.05 .

\section{RESULTS}

The number of patients diagnosed with OSCCLM at IPOLFG was 479 . However, only 354 patients were used based on the inclusion and exclusion criteria only. Of those, 208 cases belonged to ATU and 146 to ATNU. Concerning the age of patients with OTSCC, the difference between ATU and ATNU regarding the mean age was significantly different according to the Student's t-test: $\mathrm{t}(352)=-3.901, \mathrm{p}=0.000 . \mathrm{p}<0.05$ (Table 1). The ATNU group presented mean age of 63.6 years (range: 29 to 87 years; greater incidence among 61-70 year old), whereas the ATU group presented a mean age of 58.8 years (range: 27 to 88 years) (Fig. 1). Considering the distribution of tobacco and/or alcohol users and non-users according to gender, there was a significant

Table 1. Comparison between alcohol and tobacco users and non-users regarding age, sex and use of removable denture.

\begin{tabular}{lcc}
\hline Criteria & Users & Non-users \\
\hline $\begin{array}{l}\text { Age } \\
\mathrm{t}(352)=-3.901 \mathrm{p}=0.000 ; \mathrm{p}<0.05\end{array}$ & 58.84 & 63.63 \\
$\begin{array}{l}\text { Men } \\
\text { Binomial, } \mathrm{p}=0.000 ; \mathrm{p}<0.05\end{array}$ & $200(79 \%)$ & $53(21 \%)$ \\
Women & & \\
Binomial, $\mathrm{p}=0.000 ; \mathrm{p}<0.05$ & $8(7.9 \%)$ & $93(92.1 \%)$ \\
$\begin{array}{l}\text { Denture use } \\
\text { Binomial, } \mathrm{p}=0.000 ; \mathrm{p}<0.05\end{array}$ & $72(52.6 \%)$ & $65(47.4 \%)$ \\
$\begin{array}{l}\text { No denture } \\
\text { Binomial, } \mathrm{p}=0.000 ; \mathrm{p}<0.05\end{array}$ & $136(62.7 \%)$ & $81(37.3 \%)$ \\
\hline
\end{tabular}


prevalence of men in the ATU group and women in the ATNU group, both with $\mathrm{p}=0.000$ and $\mathrm{p}<0.05$, according to the Binomial test (Table 1). Denture use revealed no significant difference between the ATNU and ATU groups (Binomial $\mathrm{p}=0.097$ ). However, comparing with those without denture, a significant prevalence among ATU group was observed (Binomial $\mathrm{p}=0.000$ ) (Table 1).

The lateral borders of the tongue were the most frequent carcinoma locations in both groups. However, this was not statistically significant, according to Pearson's Chi-square test: $\chi^{2}(3)=3.015, \mathrm{p}=0.397$ (Table 2).

Regarding TNM classification, the tumor size (T) showed a significant prevalence according to the Pearson's Chi-square test: T1 in the ATNU group and T3 in the ATU group: $\chi^{2}(2)=32.170, p=0.000$. T1 presented a residual value of $3.7(\mathrm{ra})$ and 5.4 in T3, with significant differences when $r a>2$ (Table 2).The presence of ganglion metastasis was significant concerning its positive results $(\mathrm{N}+)$ in the ATNU group and $\mathrm{N} 0$ in the $\operatorname{ATU}$ group $\left(\chi^{2}(1)=18.278\right.$ and $\mathrm{p}=0.000$, with a $r a$ values of 4 and 7 in the ATNU and ATU groups, respectively (Table 2 ).

Finally, when carcinomas were grouped by stage, it was detected a significant prevalence of stage I in the ATU group and stage III in the ATU group: $\chi^{2}$ (3) $=37.668, \mathrm{p}=0.000$, with a $r a$ value of 6 for stage I and 3.3 for stage III (Table 2).

\section{DISCUSSION}

When comparing the results between the ATU

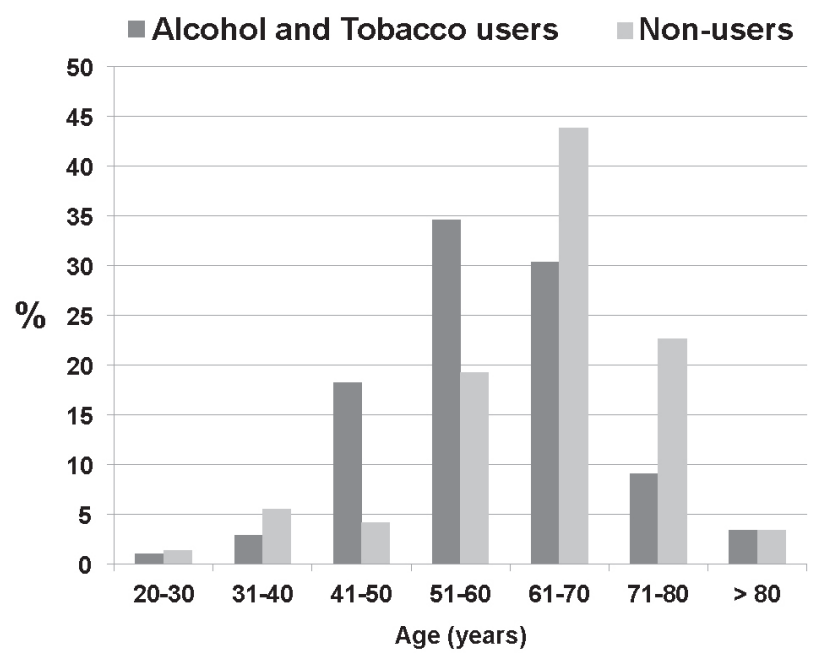

Figure 1. Distribution of alcohol and tobacco users and no-users according to the age group. and the ATNU groups, it can be noticed that the age range that concentrated the largest number of cases is different. For the ATU group, the range was between 51 and 60 years of age, while for the ATNU group it was between 61 and 70 years of age. These results agree with those of previous studies, which showed that OTSCC most commonly affects men between 60 and 80 years of age (13-15).However, further studies should be done to asses possible causes for these differences.

The IPOLFG is responsible for the treatment of carcinoma cases from the central and southern regions of Portugal, including Lisbon, Alentejo, Algarve and Madeira and Azores islands, with a total population of $5,059,432$ habitants. Some patients were admitted to their local hospital for diagnosis and treatment of tongue carcinoma in stage 1 , so the data analyzed in the present study was limited and with a population that was not representative.

Alcohol and tobacco consumption in patients with OTSCC showed a higher incidence among men, as reported elsewhere (13). The risk seems to depend

Table 2. Comparison between alcohol and tobacco users and nonusers regarding tumor location, size, cervical metastasis and stage.

\begin{tabular}{|c|c|c|}
\hline Criteria & Users & Non-users \\
\hline \multicolumn{3}{|l|}{ Location } \\
\hline Borders & $5175(59.7 \%)$ & $118(40.3 \%)$ \\
\hline Ventral surface & $20(62.5 \%)$ & $12(37.5 \%)$ \\
\hline Dorsal & $8(50.0 \%)$ & $8(50.0 \%)$ \\
\hline Vertex & $8(61.5 \%)$ & $5(38.5 \%)$ \\
\hline \multicolumn{3}{|l|}{$\chi^{2}(3)=3.015, p=0.000 ; p<0.05$} \\
\hline \multicolumn{3}{|l|}{$T$ (size) } \\
\hline $\mathrm{T} 1$ & $52(44.8 \%)$ & $64(55.2 \%)$ \\
\hline $\mathrm{T} 2$ & $84(55.3 \%)$ & $68(44.7 \%)$ \\
\hline $\mathrm{T} 3$ & $72(83.7 \%)$ & $14(16.3 \%)$ \\
\hline \multicolumn{3}{|l|}{$\chi^{2}(2)=32.170, p=0.000 ; p<0.05$} \\
\hline \multicolumn{3}{|l|}{$N$ (cervical metastasis) } \\
\hline N0 & $120(50.8 \%)$ & $120(50.8 \%)$ \\
\hline $\mathrm{N}+$ & $88(74.6 \%)$ & $88(74.6 \%)$ \\
\hline \multicolumn{3}{|l|}{$\chi^{2}(1)=18.278, p=0.000 ; p<0.05$} \\
\hline \multicolumn{3}{|l|}{ Stage } \\
\hline I & $20(5.6 \%)$ & $52(14.7 \%)$ \\
\hline II & $52(14.7 \%)$ & $28(7.9 \%)$ \\
\hline II & $80(22.6 \%)$ & $32(9.0 \%)$ \\
\hline IV & $56(15.8 \%)$ & $34(9.6 \%)$ \\
\hline$\chi^{2}(3)=37.668, p=0.000 ; p<0.05$ & & \\
\hline
\end{tabular}


on the quantity of alcohol consumed, the number of cigarettes smoked, and the type and the duration of the habit $(16,17)$. One of the limitations of this study was to determinate the exact amount of alcohol and tobacco consumed throughout the patient's life. With regard to the length of time without tobacco consumption and without direct exposure to smoke, it still not clear the time necessary for users to present a different risk from those who are non-users $(17,18)$.

Regarding denture use, the results showed a higher prevalence on non-smoker/non-drinker patients, coinciding with data published before $(19,20)$. One of the study limitations is that there was no distinction between partial and total removable dentures, neither was properly registered if denture were acrylic, chrome-cobalt or made with a different material. According to Zheng et al. (20), the use of dentures containing metal is associated with a greater risk of oral cancer, but no relationship was found when the use of acrylic dentures was examined. The presence of a higher prevalence of denture users among ATNU compared with ATU is something to take into account during diagnosis and an important factor for follow-up studies within this subgroup.

In a review article on the prevalence of various types of prosthetic dental restorations in Europe, Zitzmann et al. (21) reported that the use of removable denture in Europe varies from $13 \%$ to $29 \%$, depending of the country and found discrepant values for the prevalence of the denture use between patients and the general population. They attributed it to socioeconomic, demographic or educational factors (21). In a study in Switzerland, Menghini et al. (22) referred that denture use among people aged 50 to 79 years was $61 \%$. A study with 11,600 to 15,000 participants in Sweden conducted between 1975 and 1996 showed that use of removable partial denture among people aged 45 to 64 years old dropped from $23 \%$ to $10 \%$ (23); subjects around 65 years of age represented $23 \%$ of denture wearers (23). Furthermore, also in Sweden, Hugoson et al. (24), described that the use of removable partial denture represented $38 \%$ in 1973 and $19 \%$ in 1993, maintaining this percentage until 2003.

In the present study, however, no significance difference was found between the ATU (34.6\%) and ATNU (44.6\%) groups regarding the presence of denture, but the numbers of both groups of individuals were higher when compared with general population $(23,24)$. We believe that this result needs to be treated seriously since there are no data on denture prevalence among general Portuguese population.

In conclusion, patients with OTSCC who did not drink or smoke presented carcinoma at an older age, a smaller tumor size and a lower incidence of ganglion metastasis. Denture use had higher prevalence among non-users of alcohol and tobacco, though not significant. It is convenient to work with larger groups in order to confirm and validate these results.

\section{RESUMO}

Um aumento do carcinoma da língua, particularmente entre os não consumidores de álcool e tabaco tem se verificado recentemente. No entanto, o número de estudos que permitam uma melhor compreensão dos fatores etiológicos e características clínicas, particularmente na população Portuguesa, é muito limitado. Este estudo foi baseado em pacientes com carcinoma de dois terços anteriores da lingual que foram atendidos e tratados no Departamento de Cabeça e Pescoço do "Instituto Portugues de Oncologia de Lisboa, Francisco Gentil” (IPOLFG), Portugal, entre 1 de janeiro de 2001 e 31 de dezembro de 2009. Eles foram divididos em usuários de álcool e tabaco e não usuários, a fím de avaliar as diferenças entre estes 2 grupos com base no sexo, idade, localização do tumor, o uso de prótese dentária, tamanho do tumor, metástase e estágio. Dos 354 casos estudados, 208 eram usuários de álcool e tabaco e 146 eram não-usuários. A localização principal, em ambos os grupos, foram a bordos laterais da língua. $\mathrm{O}$ uso de prótese dentária mostrou não ter um efeito significativo em ambos os grupos de estudo. Pode-se concluir que os não-usuários de álcool e tabaco eram mais velhos e apresentaram carcinoma de menores dimensões, menor incidência de metástases ganglionares e um estágio mais inicial da doença do que os etilistas e fumantes.

\section{REFERENCES}

1. Dahlstrom KR, Little JA, Zafereo ME, Lung M, Wei Q, Sturgis EM. Squamous cell carcinoma of the head and neck in never smoker-never drinkers: a descriptive epidemiologic study. Head Neck 2008;30:75-84

2. Schmidt BL, Dierks EJ, Homer L, Potter B. Tobacco smoking history and presentation of oral squamous cell carcinoma. J Oral Maxillofac Surg 2004;62:1055-1058.

3. Slama K, David-Tchouda S, Plassart JM. Tobacco consumption among young adults in the two French departments of Savoie in 2008. Rev Epidemiol Sante Publique 2009;57:299-304.

4. Dantas DD, Ramos CC, Costa AL, Souza LB, Pinto LP. Clinicalpathological parameters in squamous cell carcinoma of the tongue. Braz Dent J 2003;14:22-25.

5. Wight R, Paleri V, Arullendran P. Current theories for the development of nonsmoking and nondrinking laryngeal carcinoma. Curr Opin Otolaryngol Head Neck Surg 2003;11:7377.

6. Goldenberg D, Lee J, Koch WM, Kim MM, Trink B, Sidransky D, et al.. Habitual risk factors for head and neck cancer. Otolaryngol Head Neck Surg 2004;131:986-993.

7. Sturgis EM, Wei Q, Spitz MR. Descriptive epidemiology and risk factors for head and neck cancer. Semin Oncol 2004;31:726-733.

8. Shiboski CH, Schmidt BL, Jordan RC. Tongue and tonsilcarcinoma increasing trends in the US population ages20-44 years. Cancer 
2005;103:1843-1849.

9. Llewellyn CD, Johnson NW, Warnakulasuriya KA. Risk factors for squamous cell carcinoma of the oral cavity in young people - a comprehensive literature review. Oral Oncol 2001;37:401-418.

10. Garavello W, Spreafico R, Gaini RM. Oral tongue cancer in young patients: a matuhed analysis. Oral Oncol 2007;43:894-897.

11. Moreno-López LA, Esparza-Gómez GC, González-Navarro A, Cerero-Lapiedra R, González-Hernández MJ, Domínguez-Rojas V. Risk of oral cancer associated with tobacco smoking, alcohol consumption and oral hygiene: a case-control study in Madrid, Spain. Oral Oncol 2000;36:170-174.

12. UICC International Union Against Cancer. TNM classification of malignant tumours. 4th edition. Berlin: Springer-Verlag 1987.

13. Moore SR, Johnson NW, Pierce AM, Wilson DF. The epidemiology of tongue cancer: a review of global incidence. Oral Dis 2000;6:75-84.

14. Bachar G, Hod R, Goldstein DP, Irish JC, Gullane PJ, Brown D, et al.. Outcome of oral tongue squamous cell carcinoma in patients with and without known risk factors. Oral Oncol 2011;47:45-50.

15. Pitman T, Jonhson T, Wagner L, Myers N. Cancer of the tongue in patients less than forly. Head \& Neck 2000;22:297-302.

16. Bagnardi V, Blangiard M, La Vecchia C, Corrao G. A meta-analysis of alcohol drinking and cancer risk. BR J Cancer 2001;85:170017005 .

17. Schmidt BL, Dierks EL, Homer L, Potter B. Tobacco smoking history and presentation of oral squamous cell carcinoma. J Oral Maxillofac Surg 2004;62:1055-1058.

18. Cann CI, Fried MP, Rothman KJ. Epidemiology of squamous cell cancer of the head and neck. Otolaryngol Clin North Am $1985 ; 18: 367-388$.
19. Lissowska J, Pilarska A, Pilarski P, Samolczyk-Wanyura D, Piekarczyk J, Bardin-Mikolłajczak A, et al.. Smoking, alcohol, diet, dentition and sexual practices in the epidemiology of oral cancer in Poland. No association-oral cáncer. Eur J Cancer Prev 2003;12:25-33.

20. Zheng TZ, Boyle P, Hu HF, Duan J, Jian PJ, Ma DQ, et al.. Dentition, oral hygiene, and risk of oral cancer: a case-control study in Beijing, People's Republic of China. Cancer Causes Control 1990;1:235-241.

21. Zitzmann NU, Hagmann E, Weiger R. What is the prevalence of various types of prosthetic dental restorations in Europe? Clin Oral Implants Res 2008;19:326-328.

22. Hugoson A, Koch G, Göthberg C, Helkimo AN, Lundin SA, Norderyd O,et al.. Oral health of individuals aged 3-80 years in Jo"nko"ping, Sweden during 30 years (1973-2003). II Review of clinical and radiographic findings. Swed Dent J 2005;29:125-138.

23. Osterberg T, Carlsson GE, Sundh V. Trends and prognoses of dental status in the Swedish population: analysis based on interviews in 1975 to 1997 by Statistics Sweden. Acta Odontol Scand 2000;58:177-182

24. Menghini G, Steiner M, Helfenstein U, Imfeld C, Brodowski D, Hoyer C, et al.. Dental health of adults in the Zurich Canton. Schweiz Monatsschr Zahnmed 2002;112:708-717.

25. Sharma P, Saxena S, Aggarwal P. Trends in the epidemiology of oral squamous cell carcinoma in Western UP: an institutional study. Indian J Dent Res 2010;21:316-319.

Received July 7, 2011

Accepted September 29, 2011 